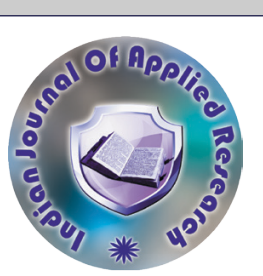

Ayurveda

\title{
AYURVEDIC INTERVENTION IN THE MANAGEMENT OF INFERTILITY ASSOCIATED WITH PCOS, A CASE STUDY
}

Dr. S. Srilatha*

\section{Dr. Kola Vijaya} kumari

Post Graduate scholar, department of Prasuti Tantra and Stree Roga, Dr. N.R.S. Govt. Ayurvedic Medical College affiliated to A.L. Govt. Ayurvedic teaching hospital, Vijayawada, Andhra Pradhesh, India. *Corresponding Author

Associate Professor \& HOD, department of Prasuti Tantra and Stree Roga, Dr. N.R.S. Govt. Ayurvedic Medical College affiliated to A.L. Govt. Ayurvedic teaching hospital, Vijayawada, Andhra Pradhesh, India.

ABSTRACT Infertility is a failure to conceive within one or more years of regular unprotected coitus. ovulatory factor comprises 30 $40 \%$ of infertility causes, out of this ovulatory factors PCOS is the major one. Polycystic ovarian syndrome is manifested by amenorrhea, hirsutism, and obesity associated with enlarged polycystic ovaries. And this infertility brings marital conflicts, social rejections which may leads to anxiety, disappointments and depression. In Ayurveda, vandyatwa is vatha dosha pradhana vyadi, especially apana vatha which is responsible for all menstrual and ovulatory functions. As the vasthi, the panchakarma procedure is best for vatha vyadis, in this present article a patient of infertility associated with pcos is successfully treated by matravasthi with phala tailam and oral administration of devadrumadi churnam.

KEYWORDS : Phala Tailam, Devadrumadi Churnam, Vandhyatwa, Vatha Vyadhi, Infertility.

\section{INTRODUCTION}

To become a mother is one of the most important desires of every women and every human being has intense desire to continue their own race. Failure to achieve conception by a couple of mature age, having normal unprotected coitus during appropriate period of menstrual cycle regularly, at least for one year of time period isconsidered as infertility. As per Ayurveda, the factors responsible for conception are Rtu (fertile period/ ovulatory period), Kshetra (uterus \& female reproductive system), Ambu (proper nutrient fluid) Bheeja (shukra, shonitha i.e sperm and ovum) and also normalcy of manas (Psychology).

As per Ayurveda, the balanced state of doshas is mainly responsible for health and any derangement to this doshas will leads to disease. Vandhyatwa is not an independent disease, rather an important feature of so many diseases among which PCOS is found out to be a major cause. Vandhyatwa is a vatha dominated sannipathaja vyadhi and but the out look of the symptoms of PCOS as per modern description, it becomes clear that even though acharyas are not compiled as a syndrome, in Ayurveda most of them described as features of separate disease, this disease basically caused by the vitiated kapha dosha deranging the function of the vatha dosha as well. It has been observed that Ayurveda helps in treating infertility associated with PCOS. Ayurvedic medication and pancha karmas like vasthi helps by not only treating the symptoms but also by strengthening the reproductive system and improving the local cellular immunity. In this present case study phalataila matra vasthi and devadrumadi churna has been used in infertility associate with PCOS.

\section{CASE REPORT}

A 27 years old female patient, house wife by occupation visited the OPD of A.L. Govt. ayurvedic hospital affiliated to Dr. NRS. Govt. ayurvedic college, department of Prasuti tantra and stree roga on $4^{\text {th }}$ may; 2019 With complaining of inability to conceive after 4years of marital life associated with irregular menstruation with scanty bleeding with length of the cycle 2 to 3 months, detailed history relieved that she had irregular menstruation since menarche, 2 years ago she went an allopathic hospital, then shewas diagnosed with PCOS also taken some medication for PCOS but she was not satisfied, now she approached A.L. Govt. Ayurvedic hospital for further for further management.

\section{Past history}

NO H/O DM/HTN/Thyroid dysfunction or any other major medical problems and nil surgical

\section{Family history}

No H/O same illness in any others of her family
M.H- 2-3days/2-3months/Bleeding bright red in colour, scanty flow $1 \mathrm{pad} /$ day, without clots and foul smell with history of dysmenorrhea.

Marital life: 4 years

Obstetrical history: G0 P0 L0 A0 D0

Contraception: couple not at all used any type of conception.

\section{General examination}

Built

obese

Nourishment

good

Pulse

$72 /$ minute

$\mathrm{Bp}$

$110 / 70 \mathrm{mmHg}$

Temp

normal

Respiratory rate

18times/minute

Height

$5.3 \mathrm{feet}(161.544 \mathrm{cms})$

Weight

$108 \mathrm{kgs}$

BMI

Tongue

uncoated

Pallor/cynosis/clubbing/oedema/ lymphadenopathy

absent

\section{Systemic examination}

CVS

s1, s2 normal

CNS

Conscious and well organised

B/LAirway clear, lungs clear no added sounds

$\mathrm{P} / \mathrm{A}$

soft

$\mathrm{P} / \mathrm{S}$

Cervix healthy, and nulliparous Oss, Mild white discharge present

Uterus anteverted, normal size, mobile, all fornix free 


\section{Ashta vidha pareeksha}

Nadi

$72 /$ minute

Mala

once in a day

Mutra

2-3 times per day

Jihwa

aliptha

Sabda

prakrutha

Sparsha

prakruta

Druk

prakruta

Akruthi

sthoulya

\section{Dasha vida pareeksha}

Prakruti

vatha-kapha

Vikruti

madhyama

Sara

madhyama

Samhanana

madhyama

Pramana

madhyama

Satmya

madhyama

Satva

madhyama

\section{Intervention}

Phala taila matra vasthi with the dosage of $60 \mathrm{ml}$ for 8 days following menstruation( $5^{t}$ of LMP) for 3 consective cycles.

Devadrumadi churnam 3 grams (1tsf) twice a day with honey.

\section{LAB INVESTIGATIONS}

USG Abdomen before treatment on $06|05| 2019$

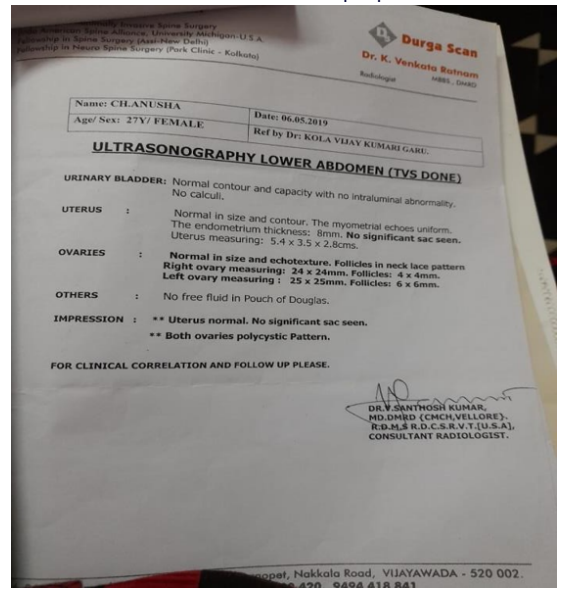

USG Abdomen after treatment on 13|12|2019

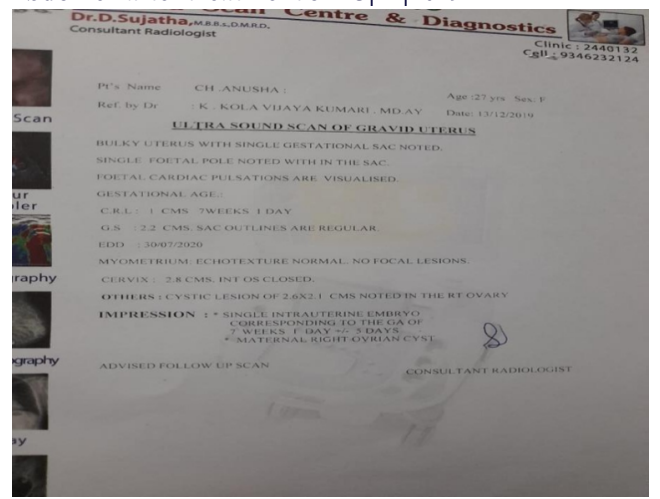

Observations and results

\begin{tabular}{|c|c|}
\hline Date & Complaints and observations \\
\hline $\mid \overline{6|5| 2019}$ & 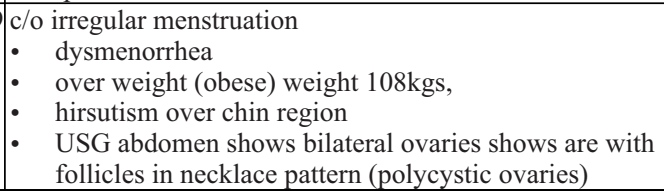 \\
\hline$|12| 9 \mid 19$ & \begin{tabular}{|l} 
After completion of course of treatment (vasthi) \\
- $\quad$ Getting regular periods without any modern tablet \\
- $\quad$ Relied from dysmenorrhea \\
- $2 \mathrm{kgs}$ of Weight reduced (106 kgs) \\
\end{tabular} \\
\hline $25|10| 19$ & Patient conceived conformed by UPT \\
\hline$|13| 12 \mid 19$ & $\begin{array}{l}\text { USG abdomen } \\
\text { - } \quad \text { CRL } 1 \mathrm{cms} 7 \text { weeks } 1 \text { day } \\
\text { G.S } 2.2 \mathrm{cms} \text { sac out ling are regular } \\
\text { - } \\
\text { EDD } 30|7| 2020 \\
\text { Impression: single live intrauterine embryo } \\
\text { corresponding to age of } 7 \text { weeks 1day. }\end{array}$ \\
\hline
\end{tabular}

\section{DISCUSSION}

As per Ayurveda infertility associated with PCOS is mainly due to vitiated kapha dosha deranging the functions of vatha dosha as well. Vitiation of Kapha dosha - manifests the symptoms loke increased in weight, infertility, hirsutism, diabetic tendencies.

Vatha dosha mainly Apana vatha, a type of vatha dosha which is mainly responsible for all menstrual and ovulatory functions. Vitiation of vatha dosha- manifest the symptoms like painful menstruation, scanty less menstrual blood, and severe.

Herbal drugs present in phala tailam and devadrumadi churna are mainly having katu tikta rasa, ushna virya, katu vipaka, laghu ruksha guna and ushna virya can cause vatha anulomana (normalise the vatha dosha) and due to katu, tikta rasa and katuvipaka ama pachana will occur and leads to srotovishodana i.e medovaha srotho sudhi and arthavaha srotosudhi. Hence in females it is used to treat infertility, pcos, reproductive system related problems.

\section{CONCLUSION}

In this particular case the vitiated kapha dosha deranging the functions of vatha dosha. these vitiated vatha kapha dhosha may leads to diminished physiological action of kayaghni and leads to accumulation of ama, which cause the sroto dusti/ sroto avaroda. vasthi is the best panchakarma procedure for vatha vyadhis, and taila is also best in treating vatha, and the ingredients present in phala taila, devadrumadi churna are also having kapha vathahara properties, hence with this Phala taila matra vasthi, we can improve jataraghni and vitiated ama can removed from the body and functions of dhatwagni gets improved, relief from sroto avarodha, which in turn helps in ovulation by balance the hormones in body and also improves the fertility.

\section{REFERENCE}

1. Prasuti Tiwari, Ayurvediya Prasuti Tantra and Stree Roga, 2nd Volume: Varanasi, Page Prasuti Tiwari,

2. D.c Duttas text book of Obstetrics, Edited by Hiralal Konar, New Central Book Agency Publication, 6th Edition, Page - 666, Page-169.

3. Kasyapa Samhita or Vrddhi Jivaka Tantra By P.V Tewari, Chaukhambha Visvabharati Oriental Publishers and Distributors, Haridas Ayurveda Series-2, page 538-539. 